\title{
Drench Application of Fish-derived Protein Hydrolysates Affects Lettuce Growth, Chlorophyll Content, and Gas Exchange
}

\author{
Chenping $\mathrm{Xu}^{1}$ and Beiquan Mou
}

ADDITIONAL INDEX WORDs. Lactuca sativa, biostimulant, photosynthesis

Summary. Protein hydrolysates (PHs) are an important group of plant biostimulants that have received increasing attention in recent years because of their positive effects on crop performance and contribution to agroecological sustainability. The aim of the study was to determine the effects of fish-derived PHs on growth, chlorophyll content and fluorescence, and leaf gas exchange of lettuce (Lactuca sativa) grown in a growth chamber. Fish-derived PHs were drench applied $(300 \mathrm{~mL}$ of $3 \mathrm{~mL} \cdot \mathrm{L}^{-1}$ ) three times at 0,14 , and 24 days after transplanting (DAT), and lettuce were evaluated 30 DAT. Application of PHs significantly increased the lettuce leaf number per plant from 22 to 28 , stem diameter from 1.37 to $1.68 \mathrm{~cm}$, shoot fresh and dry weight (FW and DW) from 59 to $89 \mathrm{~g}$ and 5.5 to $7.7 \mathrm{~g}$, and root dry weight from 0.52 to $0.80 \mathrm{~g}$. It also significantly increased the leaf relative water content (RWC) from $87 \%$ to $90 \%$ and succulence from 267 to $288 \mathrm{~g} \cdot \mathrm{m}^{-2}$ water, but had no effect on specific leaf area (SLA). PHs significantly enhanced chlorophyll content, photosynthetic rate, stomatal conductance, and transpiration rate although they did not alter chlorophyll fluorescence. Our study indicated that plant biostimulants and fertilizer PHs improved plant performance and might have potential to be used for sustainable production of lettuce.

$\mathrm{E}$ xtensive applications of synthetic chemical fertilizers have been widely practiced to meet food demand around the world (Matson et al., 1997). However, they can cause considerable damage to the ecology of agricultural systems and reduce the nutritional quality of crops. The use of biostimulants to enhance crop growth and yield has gained considerable momentum for ecological sustainability and consumer health (Calvo et al., 2014; du Jardin, 2015). Biostimulants are substances enhancing plant growth and development when applied in small quantity (Calvo et al., 2014; du Jardin, 2015; Kauffman III et al., 2007). Based on original sources, they are generally classified into several major groups: humic/fulvic acid substances, seaweed bioactive extracts, protein

U.S. Department of Agriculture, Agricultural Research Service, U.S. Agricultural Research Station, 1636 East Alisal Street, Salinas, CA 93905.

This research was supported by a grant from the California Department of Food and Agriculture Specialty Crop Block Grant Program (SCB 13047). Mention of trade names or commercial products in this publication is solely for the purpose of providing specific information and does not imply recommendation or endorsement by the U.S. Department of Agriculture. USDA is an equal opportunity provider and employer.

${ }^{1}$ Corresponding author. E-mail: cpxu1999@hotmail. com.

doi: 10.21273/HORTTECH03723-17 hydrolysates, chitosan and other biopolymers, and beneficial microorganisms (Calvo et al., 2014; du Jardin, 2015). PHs consist of oligo and polypeptides and free amino acids obtained through chemical and enzymatic hydrolysis of plant or animal sources (Cavani et al., 2006; Ertani et al., 2009, 2013; Parrado et al., 2008). They have been reported to improve crop performances by increasing shoot and root biomass, water and nutrient use efficiency, improving crop quality in terms of phytochemicals, and enhancing crop tolerance against abiotic stresses (Calvo et al., 2014; Colla et al., 2015).

Lettuce is one of the most important salad vegetables in the United States and contains important phytochemicals, including vitamins, carotenoids, and other antioxidants (Humphries and Khachik, 2003; Nicolle et al., 2004). Colla et al. (2013) found that the full-strength nutrient foliar application of plantderived PHs had no effects on lettuce FW and DW, leaf nitrogen $(\mathrm{N})$ content, and chlorophyll index, although it had positive effects in reduced nutrient solutions. Botta (2013) also reported that the foliar application of $\mathrm{PHs}$ enhanced lettuce growth under cold stress but it had no effects on FW without cold stress. Similarly, Lucini et al. (2015) found that PHs increased the lettuce shoot FW and $\mathrm{N}$ content in salinity stress but it had no effects without salinity stress. However, these studies were conducted using either hydroponics (Colla et al., 2013) or soilless medium such as sand (Botta, 2013) or peat/perlite (Lucini et al., 2015). The effects of PHs on crops grown with soilless medium or in hydroponic conditions might be different from those with soil because PHs could increase soil microbial activity (García-Martínez et al., 2010). The objective of this study was to assess the effects of fish-derived PHs on lettuce growth, chlorophyll, and gas exchange using field soil.

\section{Materials and methods}

PLANT MATERIALS AND TREATMENTS. Two weeks after sowing in trays filled with growing mix (Sun Gro Horticulture, Agawam, MA), uniform-sized lettuce seedlings (cv. Heart's Delight) were transplanted into plastic pots (6 inches diameter, 6.7 inches depth, and one plant per pot), with a single, bottom drain hole filled with $3 \mathrm{~kg}$ of sandy loam soil collected from the farm field of the United States Department of Agriculture, Agricultural Research

\begin{tabular}{llll}
\hline $\begin{array}{l}\text { Units } \\
\begin{array}{l}\text { To convert U.S. to SI, } \\
\text { multiply by }\end{array}\end{array}$ & U.S. unit & SI unit & $\begin{array}{l}\text { To convert SI to U.S., } \\
\text { multiply by }\end{array}$ \\
\hline 10 & $\%$ & $\mathrm{mg} \cdot \mathrm{g}^{-1}$ & 0.1 \\
29.5735 & $\mathrm{fl} \mathrm{oz}$ & $\mathrm{mL}$ & 0.0338 \\
2.54 & inch $(\mathrm{es})$ & $\mathrm{cm}$ & 0.3937 \\
0.2276 & inch $/ \mathrm{oz}$ & $\mathrm{cm}{ }^{2} \cdot \mathrm{g}^{-1}$ & 4.3942 \\
0.4536 & $\mathrm{lb}$ & $\mathrm{kg}$ & 2.2046 \\
28.3495 & $\mathrm{oz}$ & $\mathrm{g}$ & 0.0353 \\
28,350 & $\mathrm{oz}$ & $\mathrm{mg}$ & $3.5274 \times 10^{-5}$ \\
33.9057 & $\mathrm{oz} / \mathrm{yard}{ }^{2}$ & $\mathrm{~g} \cdot \mathrm{m}^{-2}$ & 0.0295 \\
1 & $\mathrm{ppm}$ & $\mathrm{mg} \cdot \mathrm{L}^{-1}$ & 1 \\
0.001 & $\mathrm{ppm}$ & $\mathrm{mL} \cdot \mathrm{L}^{-1}$ & 1,000 \\
$\left({ }^{\circ} \mathrm{F}-32\right) \div 1.8$ & ${ }^{\circ} \mathrm{F}$ & ${ }^{\circ} \mathrm{C}$ & $\left({ }^{\circ} \mathrm{C} \times 1.8\right)+32$
\end{tabular}


Service in Salinas, CA (lat. $36^{\circ} 40^{\prime} 40^{\prime \prime} \mathrm{N}$, long. $\left.121^{\circ} 39^{\prime} 20^{\prime \prime} \mathrm{W}\right)$. Then, pots were watered to field capacity with full-strength Hoagland's nutrient solution (Hoagland and Arnon, 1950) either without (control) or with (PHs treatment) $3 \mathrm{~mL} \cdot \mathrm{L}^{-1}$ of fish-derived PHs (C.R. Brown Enterprises, Andrews, $\mathrm{NC}$ ) which contain $2 \% \mathrm{~N}, 1.3 \%$ phosphorus $(\mathrm{P}), 0.8 \%$ potassium $(\mathrm{K}), 0.2 \%$ calcium $(\mathrm{Ca}), 0.1 \%$ magnesium $(\mathrm{Mg})$, and $1.3 \%$ sulfur $(S)$. The eight pots of lettuce for each treatment were moved to a reach-in growth chamber, and the environment in the growth chamber was maintained at day/ night temperatures of $20 / 15^{\circ} \mathrm{C}$ and a photoperiod of $14 \mathrm{~h}$ with $700 \mu \mathrm{mol} \cdot \mathrm{m}^{-2} \cdot \mathrm{s}^{-1}$ photosynthetic photon flux (PPF). Pots were rotated and irrigated twice weekly, and irrigation volumes were determined by weighing each pot at field capacity and again just before irrigation. The weight loss per pot was assumed to equal total evapotranspiration and its equivalent amount of water was applied for each pot. For PHs treatment, plants were watered with fish-derived PHs three times $\left(300 \mathrm{~mL}\right.$ of $\left.3 \mathrm{~mL} \cdot \mathrm{L}^{-1}\right)$ at 0,14 , and 24 DAT according to the manufacturer's guidelines, whereas control plants were applied with water only. A complete randomized design was used for this experiment with eight replicates for each treatment.

GAS EXCHANGE AND FLUORESCENCE MEASUREMENTS. Thirty DAT, leaf maximum photochemical efficiency $\left(F_{\mathrm{v}} / F_{\mathrm{m}}\right)$, photochemical yield [Y(II)], and electron transport rate (ETR) were measured with a fluorometer (MINI-PAM-II; Heinz Walz, Effeltrich, Germany) on the two largest leaves of each plant. Leaf $F_{\mathrm{v}} / F_{\mathrm{m}}$ was measured after leaves were adapted in darkness for $30 \mathrm{~min}$. Leaf net photosynthetic rate $(\mathrm{Pn})$, transpiration rate $(\mathrm{Tr})$, and stomatal conductance ( $\left.g_{\mathrm{S}}\right)$ were determined on the two largest leaves of each plant using a portable IR gas analyzer (LI-6400XT; LICOR, Lincoln, NE). The analyzer was set at a flow rate of $500 \mu \mathrm{mol} \cdot \mathrm{s}^{-1}$, leaf temperature of $20 \pm 0.4{ }^{\circ} \mathrm{C}$, relative humidity of $60 \% \pm 5 \%$, and a light emitting diode external light source providing a $P P F$ density of $700 \mu \mathrm{mol} \cdot \mathrm{m}^{-2} \cdot \mathrm{s}^{-1}$.

GROWTH AND CHLOROPHYLL CONTENT MEASUREMENTS. Plants were harvested at 30 DAT to measure the leaf number, shoot FW and DW, stem diameter, and root DW. Sample DW was measured after drying at $65^{\circ} \mathrm{C}$ for $3 \mathrm{~d}$. Leaf discs were collected using a cork borer from the four largest leaves of each plant to measure RWC, SLA, succulence, and chlorophyll content. The SLA was calculated as SLA = leaf area/DW (Evans, 1972). Leaf RWC was calculated as $\mathrm{RWC}(\%)=100 \times[(\mathrm{FW}-\mathrm{DW}) /(\mathrm{TW}-$ DW)], where TW is turgid weight after being soaked in water for $3 \mathrm{~h}$ at $4{ }^{\circ} \mathrm{C}$ (Barr and Weatherley, 1962). Succulence was calculated as water content per unit leaf area (Longstreth and Nobel, 1979). Leaf pigments were extracted with methanol and absorbance of the extraction was measured at 665 and $652 \mathrm{~nm}\left(A_{665}\right.$ and $\left.A_{652}\right)$ with a spectrophotometer (Genesys; Spectronic Instruments, Rochester, NY). Chlorophyll a and chlorophyll b contents $(\mathrm{Ca}$ and $\mathrm{Cb}$ ) were calculated using the formula described by Lichtenthaler (1987): Ca (milligrams per liter $)=16.72 \times A_{665}-9.16 \times A_{652}$; $\mathrm{Cb}$ (milligrams per liter $)=34.09 \times$ $A_{652}-15.28 \times A_{665}$.

Statistical anAlysis. All data were subjected to one-way analysis of variance according to the general linear model using the JMP program (version 5; SAS Institute, Cary, NC). The mean values of each measured variable in lettuce growth, gas exchange, chlorophyll content, and fluorescence were separated between control and $\mathrm{PHs}$ treatments by Student's $t$ test at the 0.05 level of probability.

\section{Results and discussion}

Compared with the control, $\mathrm{PHs}$ treated plants had greatly enhanced growth (Fig. 1). The protein hydrolysate treatment significantly increased leaf
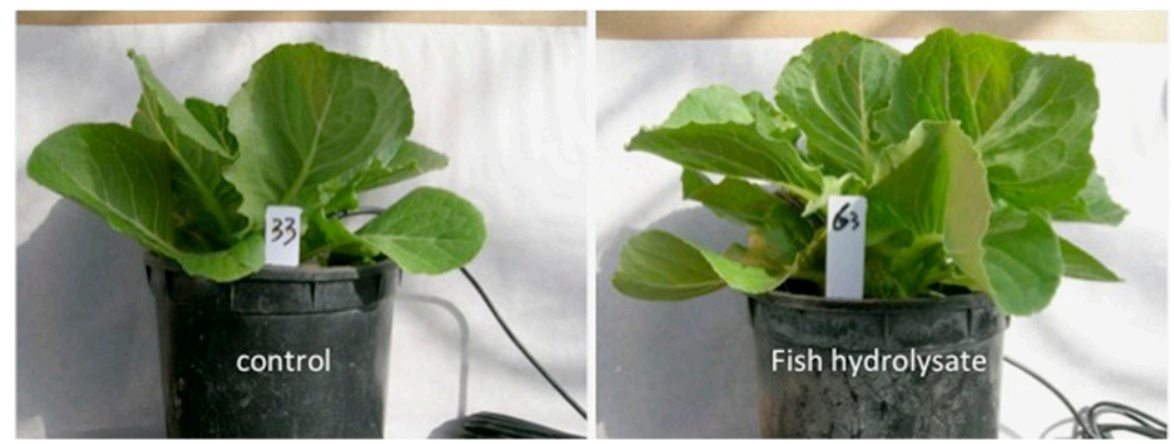

Fig. 1. Representative lettuce plants $30 \mathrm{~d}$ after transplanting from control (left) and fish-derived protein hydrolysate treatments (right). numbers from 22 to 28 leaves/plant (Table 1) and stem diameter from 1.37 to $1.68 \mathrm{~cm}$ (Table 1). A high number of functional leaves are essential for crop production, especially for leafy vegetables such as lettuce. The protein hydrolysate treatment significantly increased shoot FW, DW, and root DW from 59 to $89 \mathrm{~g}, 5.5$ to $7.7 \mathrm{~g}$, and 0.52 to $0.80 \mathrm{~g}$, respectively (Table 1). Consistent with the present study, PHs have been identified to enhance plant growth of many crops such as corn [Zea mays (Ertani et al., 2009)], kiwifruit [Actinidia deliciosa (Quartieri et al., 2002)], banana [Musa acuminate (Gurav and Jadhav, 2013)], papaya [Carica papaya (MoralesPajan and Stall, 2003)], passionfruit [Passiflora edulis (Morales-Pajan and Stall, 2004)], pepper [Capsicum annuum (Ertani et al., 2014)], tomato [Solanum lycopersicum (Colla et al., 2014; Parrado et al., 2008)], radish [Raphanus satious (Liu et al., 2008)], and lily [Lilium (De Lucia and Vecchietti, 2012)]. The growth enhancement by PHs has been attributed to increased nutrient uptake, assimilation, and metabolism resulting from increases in soil microbial activity, improvement of micronutrient mobility and solubility, modifications in the root architecture of plants, in particular root length, density and number of lateral roots, and increases in activities of enzymes involved in nutrient metabolism (Colla et al., 2014, 2015; García-Martínez et al., 2010; Lucini et al., 2015).

The $\mathrm{N}$ assimilation process is key to controlling plant growth and development. Maini (2006) summarized that $\mathrm{PHs}$ application enhanced the activity of glutamate dehydrogenase, nitrate reductase, and malate dehydrogenase in corn. Similarly, 


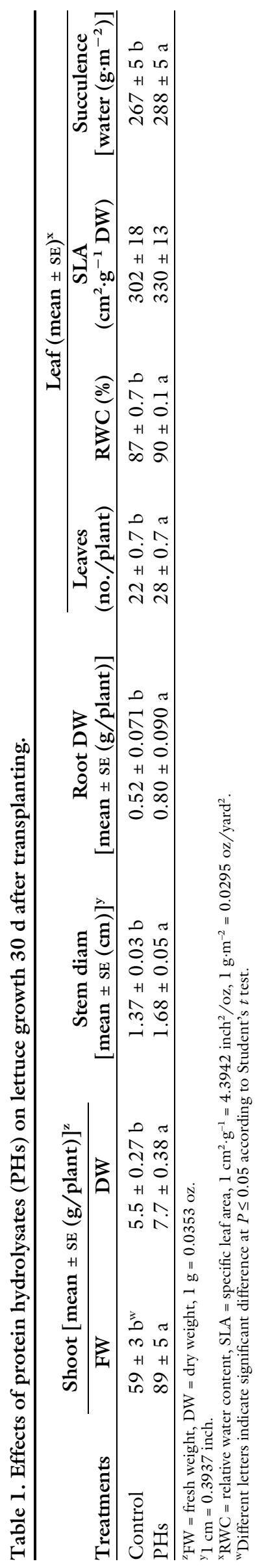

PHs application was reported to increase activities of nitrate reductase, glutamine synthetase and glutamate synthase in corn leaves (Ertani et al., 2009, 2013), radish leaves (Liu et al., 2008), and bean (Phaseolus vulgaris) leaves and roots (Baglieri et al., 2014). Colla et al. (2013, 2014) found that PHs increased leaf $\mathrm{N}$ content of corn and tomato. Other studies have demonstrated that $\mathrm{PH}$ supplied to corn plants influence different metabolic pathways, such as glycolysis and the Krebs cycle. Schiavon et al. (2008) demonstrated that the activity of enzymes involved in carbon metabolism, such as malate dehydrogenase, isocitrate dehydrogenase, and citrate synthase, and $\mathrm{N}$ reduction and assimilation, such as nitrate reductase, nitrite reductase, glutamine synthetase, glutamate synthase, and aspartate aminotransferase, were stimulated in corn seedlings by PHs application. In addition, application of plant-derived $\mathrm{PH}$ enhanced iron $(\mathrm{Fe})$-chelate reductase activity and $\mathrm{Fe}$ uptake in tomato plants (Cerdán et al., 2013). Although only small amount of N, P, K (about $55 \mathrm{mg} \mathrm{N}, 35 \mathrm{mg} \mathrm{P}$, and $22 \mathrm{mg} \mathrm{K}$ per plant, respectively), $\mathrm{Ca}, \mathrm{Mg}$, and $\mathrm{S}$ contained in $\mathrm{PH}$ were applied in this study, it is possible that they might also contribute to improved lettuce growth.

Despite positive effects on crop growth and production observed in many studies, other studies still indicated that PHs had no effect or even damaged plant growth. Although they improved stress tolerance against salinity, cold, or nutrient deficiency, PHs had no effects on lettuce growth without stress (Botta, 2013; Colla et al., 2013; Lucini et al., 2015). Addition of amino acids to the nutrient solution did not alter tomato growth (Garcia et al., 2011). Animalderived $\mathrm{PHs}$ even caused tomato plant growth inhibitions (Cerdán et al., 2009, 2013) and had no beneficial influence on strawberry (Fragaria $\times$ ananassa) growth (Lisiecka et al., 2011). Overall, these studies involved different $\mathrm{PHs}$ derived from different sources (plant or animal origin) and prepared by a range of different groups. Also, PHs effects might be altered by different growth medium and/or plant species. Hence, any variations among studies may be attributed to the different $\mathrm{PHs}$, application methods, plant species and/or growth conditions.

Protein hydrolysate treatment in the present study significantly increased chlorophyll a content from 8.2 to $10.3 \mathrm{mg} \cdot \mathrm{g}^{-1} \mathrm{DW}$, chlorophyll b content from 1.4 to $1.9 \mathrm{mg} \cdot \mathrm{g}^{-1}$ DW, and total chlorophyll content from 9.6 to $12.2 \mathrm{mg} \cdot \mathrm{g}^{-1} \mathrm{DW}$ (Table $2)$. However, it had no effect on chlorophyll fluorescence including photochemical efficiency, yield, and ETR (Table 2). Colla et al. (2013, 2014) and Ertani et al. (2013) reported that plant-derived $\mathrm{PHs}$ increased chlorophyll index of corn and tomato seedlings, whereas other studies found that PHs had no effects on chlorophyll index in lettuce (Colla et al., 2015; Lucini et al., 2015) and chlorophyll content in perennial ryegrass [Lolium perenne (Botta, 2013)]. Cerdán et al. (2013) found that plantderived $\mathrm{PHs}$ increased chlorophyll content in tomato leaves, but animalderived $\mathrm{PH}$ did not alter chlorophyll content. Garcia et al. (2011) reported that addition of amino acids to the nutrient solution increased chlorophyll concentration in tomato leaves. Baglieri et al. (2014) reported that insoluble $\mathrm{PHs}$ derived from tomato plants increased chlorophyll a content in bean plants, whereas soluble PHs had no effect. Similarly, the influences of PHs on chlorophyll fluorescence were not consistent. Although PHs increased ryegrass photochemical efficiency in heat stress, they had no effects without stress (Botta, 2013; Kauffman III et al., 2007). Lucini et al. (2015) reported that PHs enhanced lettuce photochemical efficiency either with or without salt stress. Again the inconsistency might result from different $\mathrm{PHs}$, plant species and/or growth conditions.

Although many researches focused on crop growth, there are very limited reports on leaf water relation or gas exchange as affected by PHs. In this study, PHs treatment significantly increased leaf RWC and succulence from $87 \%$ to $90 \%$ and 267 to $288 \mathrm{~g} \cdot \mathrm{m}^{-2}$ water, respectively (Table 1). This suggests that PHs application could improve lettuce quality. However, the SLA was not altered by PHs treatment in the present study (Table 1). Leaf $\mathrm{Pn}, \mathrm{Tr}$, and $g_{\mathrm{s}}$ were enhanced by PHs treatment in the present study from 12.2 to $16.9 \mu \mathrm{mol} \cdot \mathrm{m}^{-2} \cdot \mathrm{s}^{-1}$ carbon dioxide, 2.9 to $4.0 \mathrm{mmol} \cdot \mathrm{m}^{-2} \cdot \mathrm{s}^{-1}$ 


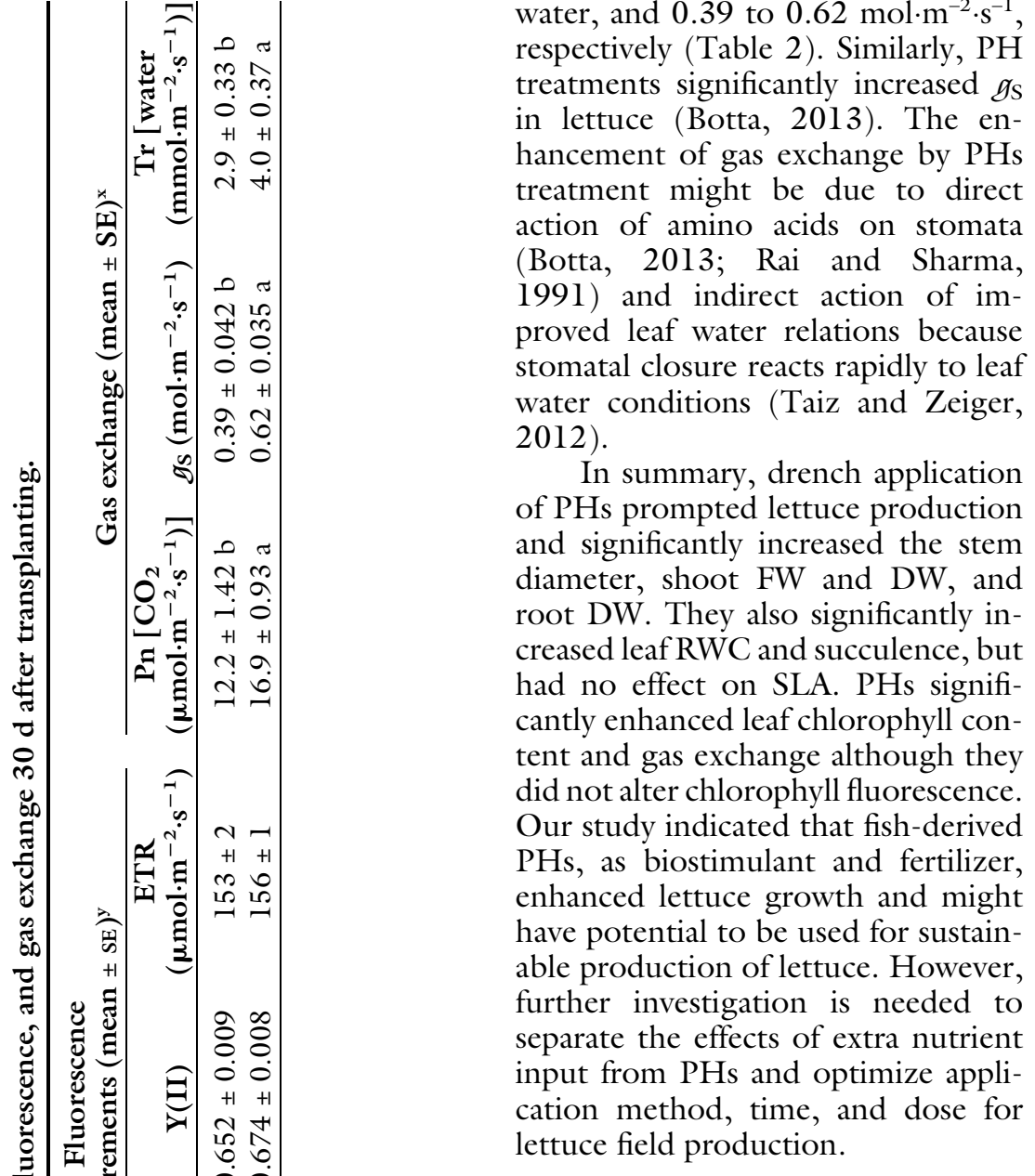

\section{Literature cited}

Baglieri, A., V. Cadili, C.M. Monterumici, M. Gennari, S. Tabasso, E. Montoneri, S. Nardi, and M. Negre. 2014. Fertilization of bean plants with tomato plants hydrolysates: Effect on biomass production, chlorophyll content and $\mathrm{N}$ assimilation. Sci. Hort. 176:194-199.

Barr, H.D. and P.E. Weatherley. 1962. A re-examination of the relative turgidity technique for estimating water deficit in leaves. Austral. J. Biol. Sci. 15:413-428.

Botta, A. 2013. Enhancing plant tolerance to temperature stress with amino acids: An approach to their mode of action. Acta Hort. 1009:29-35.

Calvo, P., L. Nelson, and J.W. Kloepper. 2014. Agricultural uses of plant biostimulants. Plant Soil 383:3-41.

Cavani, L., A.T. Halle, C. Richard, and C. Ciavatta. 2006. Photosensitizing properties of protein hydrolysate-based fertilizers. J. Agr. Food Chem. 54:9160-9167.

Cerdán, M., A. Sánchez-Sánchez, D.J. Jordá, M. Juárez, and J.S. Andreu. 2013. Effect of commercial amino acids on iron nutrition of tomato plants grown under lime-induced iron deficiency. J. Plant Nutr. Soil Sci. 176:1-8.

Cerdán, M., A. Sánchez-Sánchez, M. Oliver, M. Juárez, and J.J. Sánchez-Andreu. 2009. Effect of foliar and root applications of amino acids on iron uptake by tomato plants. Acta Hort. 830:481488.

Colla, G., S. Nardi, M. Cardarelli, A. Ertani, L. Lucini, R. Canaguier, and Y. Rouphael. 2015. Protein hydrolysates as biostimulants in horticulture. Sci. Hort. 196:28-38.

Colla, G., Y. Rouphael, R. Canaguier, E. Svecova, and M. Cardarelli. 2014. Biostimulant action of a plant-derived protein hydrolysate produced through enzymatic hydrolysis. Front. Plant Sci. 5:448.

Colla, G., E. Svecova, Y. Rouphael, M. Cardarelli, H. Reynaud, R. Canaguier, and B. Planques. 2013. Effectiveness of a plant -derived protein hydrolysate to improve crop performances under different growing conditions. Acta Hort. 1009:175-179.

De Lucia, B. and L. Vecchietti. 2012. Type of bio-stimulant and application method effects on stem quality and root system growth in LA lily. Eur. J. Hort. Sci. $77: 10-15$.

du Jardin, P. 2015. Plant biostimulants: Definition, concept, main categories and regulation. Sci. Hort. 196:3-14.

Ertani, A., L. Cavani, D. Pizzeghello, E. Brandellero, A. Altissimo, C. Ciavatta, and S. Nardi. 2009. Biostimulant activities of two protein hydrolysates on the growth and nitrogen metabolism in maize seedlings. J. Plant Nutr. Soil Sci. 172:237244.

Ertani, A., D. Pizzeghello, O. Francioso, P. Sambo, S. Sanchez-Cortes, and S. Nardi. 2014. Capsicum chinensis L. growth and nutraceutical properties are enhanced by biostimulants in a long-term period: Chemical and metabolomics approaches. Front. Plant Sci. 5:375.

Ertani, A., M. Schiavon, A. Muscolo, and S. Nardi. 2013. Alfalfa plant-derived biostimulant stimulate short-term growth of salt stressed Zea mays L. plants. Plant Soil 364:145-158.

Evans, G.C. 1972. The quantitative analysis of plant growth. Univ. California Press, Berkeley, CA.

Garcia, A.L., R. Madrid, V. Gimeno, W.M. Rodriguez-Ortega, N. Nicolas, and F. Garcia-Sanchez. 2011. The effects of amino acids fertilization incorporated to the nutrient solution on mineral composition and growth in tomato seedlings. Span. J. Agr. Res. 9:852-861. 
García-Martínez, A.M., A. Díaz, M. Tejada, J. Bautista, B. Rodríguez, C.S. María, E. Revilla, and J. Parrado. 2010. Enzymatic production of an organic soil biostimulant from wheat condensed distiller solubles: Effects on soil biochemistry and biodiversity. Process Biochem. 45:1127-1133.

Gurav, R.G. and J.P. Jadhav. 2013. A novel source of biofertilizer from feather biomass for banana cultivation. Environ. Sci. Pollution Res. 20:4532-4539.

Hoagland, D.R. and D.I. Arnon. 1950. The water-culture method for growing plants without soil. California Agr. Expt. Sta. Circ. 247.

Humphries, J.M. and F. Khachik. 2003. Distribution of lutein, zeaxanthin, and related geometrical isomers in fruit, vegetables, wheat, and pasta products. J. Agr. Food Chem. 51:1322-1327.

Kauffman, G.L., III., D.P. Kneival, and T.L. Watschke. 2007. Effects of biostimulant on the heat tolerance associated with photosynthetic capacity, membrane thermostability, and polyphenol production of perennial ryegrass. Crop Sci. 47: 261-267.

Lichtenthaler, H.K. 1987. Chlorophylls and carotenoids-pigments of photosynthetic biomembranes. Methods Enzymol. 148:350-382.

Lisiecka, J., M. Knaflewski, T. Spizewski, B. Fraszczak, A. Kaluzewicz, and W. Krzesinski. 2011. The effect of animal protein hydrolysate on quantity and quality of strawberry daughter plants $\mathrm{cv}$. 'Elsanta'. Acta Sci. Pol. Hortorum Cultus 10:31-40.

Liu, X.Q., K.Y. Ko, S.H. Kim, and K.S Lee. 2008. Effect of amino acid fertilization on nitrate assimilation of leafy radish and soil chemical properties in high nitrate soil. Commun. Soil Sci. Plant Anal. 39:269-281.

Longstreth, D.J. and P.S. Nobel. 1979. Salinity effects on leaf anatomy consequences for photosynthesis. Plant Physiol. 63:700-703.

Lucini, L., Y. Rouphael, M. Cardarelli, R. Canguier, P. Kumar, and G. Colla. 2015. The effect of a plant-derived biostimulant on metabolic profiling and crop performance of lettuce grown under saline conditions. Sci. Hort. 182:124-133.

Maini, P. 2006. The experience of the first biostimulant, based on amino acids and peptides: A short retrospective review on the laboratory researches and the practical results. Fertilitas Agrorum 1:29-43.

Matson, A., W.J. Parton, A.G. Power, and M.J. Swift. 1997. Agricultural intensification and ecosystem properties. Science 277:504-509.

Morales-Pajan, J.P. and W. Stall. 2004 Passion fruit (Passiflora edulis) transplant production affected by selected biostimulants. Proc. Florida State Hort Soc. 117:224-227.

Morales-Pajan, J.P. and W.M. Stall. 2003. Papaya (Carica papaya) response to foliar treatments with organic complexes of peptides and amino acids. Proc. Florida State Hort. Soc. 116:30-32.

Nicolle, C., N. Cardinault, E. Gueux, L. Jaffrelo, E. Rock, A. Mazur, P. Amouroux, and C. Rémésy. 2004. Health effect of vegetable-based diet: Lettuce consumption improves cholesterol metabolism and antioxidant status in the rat. Clin. Nutr. 23:605-614

Parrado, J., J. Bautista, E.J. Romero, A.M. Garcia-Martinez, V. Friaza, and M. Tejada. 2008. Production of a carob enzymatic extract: Potential use as a biofertilizer. Bioresour. Technol. 99:23122318.

Quartieri, M., L. Cavani, A. Lucchi, B. Marangoni, and M. Tagliavini. 2002. Effects of the rate of protein hydrolysis spray concentration on growth of potted kiwifruit (Actinidia deliciosa) plants. Acta Hort. 594:341-347.

Rai, V.K. and U.D. Sharma. 1991. Amino acids can modulate ABA induced stomatal closure, stomatal resistance and $\mathrm{K}^{+}$fluxes in Vicia faba L. leaves. Beitrage zur Biologie der Pflanzen 66:393-405.

Schiavon, M., A. Ertani, and S. Nardi. 2008. Effects of an alfalfa protein hydrolysate on the gene expression and activity of enzymes of TCA cycle and N metabolism in Zea mays L. J. Agr. Food Chem. 56:11800-11808.

Taiz, L. and E. Zeiger. 2012. Plant physiology. Sinauer Assoc., Sunderland, MA. 